Acn. iii.

390,2 ;

cf. viii.

43.

3.

§31. Coloseum ${ }^{86}$ autem palacium Titi et Uespasiani transeo. Quis enim artificiosam compositionem eius et magnitudinem sermone exequi poterit? Iuxta hoc palacium est imago suis ${ }^{87}$ quam Eneas fetam iuxta uaticinium Priamidis Eleni ${ }^{88}$ legitur reperisse, signum scilicet ciuitatis eo loco edificande quam fata sibí dederant orbi toto inperaturam. De hoc signo Uirgilius sic ait :

$$
\text { Alba solo recubans, albi circum ubera rati. }
$$

Est autem hoc signum ex Pario marmore candidissimo mira arte perfecto. Reptantque circum ubera eius nati numero .xxx.

\$32. In porticu etiam ante hiemale palatium domini pape est imago enea illius lupe que dicitur Remum et Romulum aluisse. Set hoc quidem. fabulosum est. Nam Lupa ${ }^{89}$ quedam mulier eximie pulcritudinis antiquitus Rome fuit. Hec Remum et Romulum in Tiberi proiectos inuenit, et pro suis aluit. Que ideo Lupa dicta est, quoniam pulcritudine sua et illecebris suis homines in ${ }^{\text {o }}$ amorem sươm rapiebat. Hec autem lupa enea arieti eneo insidiatur ${ }^{21}$, qui ante palatium prefatum aquam abluendis manibus ore emittit ${ }^{22}$. Lupa etiam quondam singulis mammis aquam abluendis manibus emittebat, set nunc fractis pedibus a loco suo diuulsa est.

§33. Ante hanc enea tabula est, ubi pociora legis precepta scripta 203 a. sunt: Que tabula prohibens / peccatum dicitur. In hac tabula plura legi, set pauca intellexi. Sunt enim afforism〈i $\rangle$, ubi fere omnia uerba subaudiuntur.

[The remainder of $f .203$ is cut away, leaving only a small slip at the top: the verso is blank, and probably the remainder of the recto was also blank.]

\title{
Note on the Name Magna Carta
}

Is supplement to the note on the name Magna Carta which appeared in this Review in $1915,{ }^{1}$ I now reproduce two letters from the Close Roll of 9 Henry III, which are strongly confirmatory of the view I maintained that magna carta came into use to distinguish the parent document from its offspring, the charter of the forest. In the first of these letters, not only is the carta libertatum called maior, as in 1218 ; but the contrast is even more pointed through the use of minor in the next sentence to describe the forest charter. The second letter containg the earliest absolutely proved use yet noticed of magna carta for the carta libertatum,-magna carta nostra de libertatibus. For here the words are in the original roll, whereas it will be recalled that the letter containing the term and dated February 1218 was in the duplicate or copy of

\footnotetext{
ss Doloseum.

a' suis] sciis.

- lupam. 0 in] et

21 corr. from ingideatur.

ss Piramidis eleno.

1 Ante, xxx. 472-5.

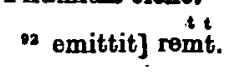


the roll for that year, though there is, to be sure, little doubt that this copy was made before 1225, the date of the present letters. The two letters, written less than a month apart and recorded on the dorse of the same membrane, were probably drawn up by the same man, and it is interesting to notice that the positive magna is used when the parent document is mentioned by itself, but the comparative form when the two charters are referred to in the same letter. ${ }^{2}$ Albert BeEBE WhIte.

Rex Vicecomiti Kanc' salutem. Precipimus tibi quod per totam Bailliam tuam puplice clamari et firmiter observari facias omnibus probis hominibus baillie tue omnes libertates quas eis concessimus contentas in maiori carta nostra de libertatibus. Clamari etiam puplice facias et firmiter observari per totam Bailliam tuam omnes libertates contentas in minori carta nostra de libertatibus foreste secundum perambulacionem factam in Baillia tua per preceptum nostrum inter partes illas que foreste remanebunt et eas que deafforestabuntur et illud idem de perambulacionibus nondum factis ex quo facte fuerint clamari facias et observari, ita quod similiter publice clametur et omnibus communiter et districte precipiatur in fide qua nobis tenentur quod sicut libertates predictas eis libere concessimus et precepimus et volumus observari; ita universi et singuli omnia iura nostra et omnes libertates nostras illesas conservent per omnia tam in forestis quam aliis. Teste me ipso apud Westmonasterium, virr. die Maii.

Eodem modo scribitur omnibus Vicecomitibus Anglie.

II

Rex eidem ${ }^{3}$ salutem. Cum omnibus de regno nostro sicut bene scitis concesserimus libertates quasdam scriptas in magna carta nostra de libertatibus, priori et monachis Dunholm' de iure deesse non possumus quin ipsi libertatibus in carta nostra predicta contentis utantur et gaudeant sicut et ceteri de regno nostro salvis vobis libertatibus vestris. Unde vobis mandamus quatinus predictos priorem et monachos quantum in vobis est plene et sine difficultate libertates suas habere permittatis secundum tenorem predicte carte nostre salvis vobis libertatibus vestris debitis et usitatis. Teste Rege apud Westmonasterium, xv. die Iunii per Iusticiarium.

- Both these letters, which have so long escaped due notice, were printed by Hardy for the Record Commissioners in Rotuli Litlerarum Clausarum, ii. 73.

'The letter which precedes this begins, Rex Dunholm' Episcopo et Cancellario suo salutem. It admonishes the bishop not to hinder the admission to the church of Heckington of a certain clerk presented by the prior and convent of Durham and also bids the bishop restore to the said prior certain lands and possessions of which the latter has been unjustly disseised by the bishop's bailiffs. Tho letter ends with laying down the principle that, while the king desires to uphold all the rights of the bishop and his church, yet, as ruler of the whole kingdom, he is no less bound to see full justice done to the prior. In the letter here printed, written nine days later, it appears to have occurred to the justiciar that the great charter, reissued four months before, was an apt expression of the same principle. 